\title{
Surface-Applied Biosolids Enhance Soil Organic Carbon and Nitrogen Stocks but Have Contrasting Effects on Soil Physical Quality
}

\author{
Virginia L. Jin, ${ }^{1}$ Kenneth N. Potter, ${ }^{2}$ Mari-Vaughn V. Johnson, ${ }^{3}$ \\ R. Daren Harmel, ${ }^{2}$ and Jeffrey G. Arnold ${ }^{2}$ \\ ${ }^{1}$ Agroecosystem Management Research Unit, United States Department of Agriculture-Agricultural Research Service (USDA-ARS), \\ 137 Keim Hall, University of Nebraska-Lincoln, Lincoln, NE 68583-0937, USA \\ ${ }^{2}$ Grassland, Soil and Water Research Laboratory, USDA-ARS, 808 East Blackland Road, Temple, TX 76502-6712, USA \\ ${ }^{3}$ Resource Assessment Division, USDA Natural Resources Conservation Service, 808 East Blackland Road, \\ Temple, TX 76502-6712, USA
}

Correspondence should be addressed to Virginia L. Jin; virginia.jin@ars.usda.gov

Received 19 September 2014; Revised 10 November 2014; Accepted 10 November 2014

Academic Editor: Leonid Perelomov

Copyright (C) 2015 Virginia L. Jin et al. This is an open access article distributed under the Creative Commons Attribution License, which permits unrestricted use, distribution, and reproduction in any medium, provided the original work is properly cited.

\begin{abstract}
Mid- to long-term impacts of land applying biosolids will depend on application rate, duration, and method; biosolids composition; and site-specific characteristics (e.g., climate, soils). This study evaluates the effects of surface-broadcast biosolids application rate and duration on soil organic carbon (SOC) stocks, soil aggregate stability, and selected soil hydraulic properties in a municipally operated, no-till forage production system. Total SOC stocks $(0-45 \mathrm{~cm}$ soil) increased nonlinearly with application rate in perennial grass fields treated for 8 years with $0,20,40$, or $60 \mathrm{Mg}$ of Class B biosolids (DM) ha $\mathrm{yr}^{-1}$ (midterm treatments). Soil organic C stocks in long-term treatment fields receiving 20 years of $20 \mathrm{Mg} \mathrm{ha}^{-1} \mathrm{yr}^{-1}$ were $36 \%$ higher than those in midterm fields treated at the same rate. Surface-applying biosolids had contrasting effects on soil physical properties. Soil bulk density was little affected by biosolids applications, but applications were associated with decreased water-stable soil aggregates, increased soil water retention, and increased available water-holding capacity. This study contrasts the potential for C storage in soils treated with surface-applied biosolids with application effects on soil physical properties, underscoring the importance of site-specific management decisions for the beneficial reuse of biosolids in agricultural settings.
\end{abstract}

\section{Introduction}

Beneficial use of biosolids is a key management tool for publicly owned treatment works (POTWs) for waste utilization and is more highly regulated than land application of animal wastes [1-3]. When applied in compliance with regulations limiting trace metals inputs and at agronomically appropriate rates, land-applied biosolids are effective soil conditioners and can supplement or replace commercial inorganic fertilizers while improving soil water conservation [4]. In addition to using biosolids amendments to restore or build soil quality, organic waste applications could promote the mitigation of atmospheric carbon dioxide levels by enhancing soil organic carbon (SOC) storage [5-7].
The quantity and frequency of inputs, method and timing of application, biosolids composition, and site edaphic factors (e.g., soils, climate) as well as other associated management practices (e.g., tillage, irrigation) affect the transfer of biosolids-C into SOC pools [7-12]. Several literature reviews show that inputs of biosolids-derived organic matter can lead to both short-term and longer-term increases in SOC $[4,7-9,13]$. Further, organic matter increases associated with land applying biosolids are often linked to improvements in soil physical quality, including decreased soil bulk density, increased soil aggregate stability, enhanced soil moisture retention, and lower soil erosion potential [5, 9-11, 14].

Soil responses to land application in no-till systems using surface-applied biosolids may differ from soil responses in 
cultivated management systems that use tillage to incorporate biosolids into surface soils. The available literature on surface-applied biosolids, particularly under field conditions, is limited relative to the number of published studies on incorporated biosolids. The objectives of this study were to evaluate the effect of application rate and duration on SOC stocks, soil aggregate stability, and selected soil hydraulic properties at a municipal biosolids recycling facility that surface-applies Class B biosolids on large-scale, no-till perennial forage production fields. Because the impact of biosolids applications on SOC and soil physical properties can be highly variable both temporally and spatially $[11,15,16]$, studies assessing the mid- and long-term effects of repeated biosolids applications, such as the one conducted here, are critical to evaluate treatment effects and system sustainability in large-scale operational settings [5].

\section{Materials and Methods}

2.1. Site and Biosolids Descriptions. This site is a publicly owned, municipally operated 485 ha, zero-discharge facility in Travis County, Texas, USA. Soils are silt loams and silty clay loams (fine-silty, mixed, superactive, thermic Cumulic Haplustolls) and are very deep ( $>2 \mathrm{~m}$ to groundwater) and well drained, with slopes $<1 \%$ [21]. Study site and management descriptions were reported previously [22] and were recently updated [17].

Biosolids are land-applied as anaerobically digested, dewatered Class B biosolids. Biosolids originate from sewage solids pumped to this recycling center from two major municipal wastewater treatment facilities servicing almost $95 \%$ of the city population $(\sim 900,000)$. Solids are separated from the wastewater and thickened using a cationic, petroleum-based dewatering polymer before and after anaerobic digestion. Thickened digested biosolids are belt-pressed to further reduce water content and then stockpiled onsite until land application. Biosolids are analyzed monthly by the POTW, which provided values for selected biosolids properties for 12 consecutive months (ranges and means from [17], Table 1). Total organic C was measured in grab-samples of stockpiled biosolids (described in the next subsection). Regulated metal loadings were well below the 40 CFR Part 503 ceiling limits (data not shown) [3].

All biosolids applications were managed by the municipal recycling facility and integrated with other facility operations. Biosolids were surface-applied with manure spreaders to 220 ha of no-till perennial forage production fields of coastal bermudagrass (Cynodon dactylon L.), which included longterm (20 yr) and midterm (8yr) application fields. All rates are reported in unit dry mass (DM). Forage was mechanically harvested multiple times per season, depending on productivity, and no grazing was used at this site. The long-term application field (14 ha) received $20 \mathrm{Mg}$ biosolids $\mathrm{ha}^{-1} \mathrm{yr}^{-1}$ from 1985 to 2005. Application rates were reduced to $5 \mathrm{Mg} \mathrm{ha}^{-1} \mathrm{yr}^{-1}$ every 2 years in 2007 to comply with the facility's nutrient management plan. A single application at this lower rate occurred before soil sampling in July 2009 (see next section). Midterm application fields were established in
2002 and consisted of 20 ha, 36 ha, and 49 ha parcels that received 20,40, and $60 \mathrm{Mg} \mathrm{ha}^{-1} \mathrm{yr}^{-1}$, respectively. Each parcel was split into two fields receiving the same application rate. Under municipal operating protocols, biosolids were applied one field at a time. Depending on field size, experimental application rate, the rate of sludge inputs from the municipality, and other operational constraints, biosolids were applied continuously to a given field until the target experimental annual treatment rate was fully applied (e.g., as short as 2-3 weeks or as long as 6-8 weeks). Surface applications would then proceed to the next field until all fields had been applied for the year. Biosolids were then stockpiled until the following year when surface applications could be resumed. Adjacent to the midterm $20 \mathrm{Mg} \mathrm{ha}^{-1} \mathrm{yr}^{-1}$ area, a 2 ha coastal bermudagrass control field has no recorded history of any nutrient inputs from biosolids, animal or green manures, or commercial fertilizer.

2.2. Soil Sampling and Analyses. Soil cores $(6.35 \mathrm{~cm}$ diameter, $\sim 50 \mathrm{~cm}$ deep) were collected in July 2009 from treated fields (unamended control; 20 dry Mg biosolids ha ${ }^{-1} \mathrm{yr}^{-1}$ for $20 \mathrm{yr}$; 20,40 , and $60 \mathrm{Mg} \mathrm{ha}^{-1} \mathrm{yr}^{-1}$ for $8 \mathrm{yr}$ ) using a truck-mounted hydraulic soil probe. Soils were collected in fields that were not undergoing active application and where biosolids had not been applied for at least 30 days before sampling to comply with POTW safety requirements and EPA 40 CFR Part 503 reentry guidelines [3], respectively. Compliance with municipal operational guidelines and federal safety guidelines resulted in sampling soils from only one field per treatment level. Paired soil cores were collected at four or five locations at $50 \mathrm{~m}$ intervals along a transect that spanned the center of each treatment field. No cores were sampled within $50 \mathrm{~m}$ of the field edge due to possible edge effects (i.e., increased soil compaction due to higher equipment traffic). Visible biosolids and plant material were removed from the soil surface prior to sampling. Each core was collected in a clear polyethylene tube liner, transported to the laboratory, and then extruded and separated into the following depth increments: $0-5,5-10,10-15,15-25,25-35$, and $35-45 \mathrm{~cm}$. Selected soil properties from July 2009 are presented for 0$30 \mathrm{~cm}$ soils collected separately from those used in this study (Table 2).

For each set of paired soil cores in all treatments, one soil core was used to determine soil bulk density $\left(D_{b}, \mathrm{Mg} \mathrm{m}^{-3}\right)$ from samples dried at $105^{\circ} \mathrm{C}$ for each depth increment. Soils from the second core were air-dried and passed through a $2 \mathrm{~mm}$ mesh sieve for all other soil physical and chemical analyses. Soil organic $\mathrm{C}$ and total $\mathrm{N}$ were measured by dry combustion (Vario Max CHN, Elementar, Hanau, Germany). Soils were combusted at $600^{\circ} \mathrm{C}$ to avoid release of soil inorganic $\mathrm{C}$, which constituted approximately $13 \%$ of total $\mathrm{C}$ in surface soils to as much as $80 \%$ in deeper soils (data not shown). Soil stocks of SOC and total N $(0-45 \mathrm{~cm}$; $\mathrm{MgC}$ or $\mathrm{Nha}^{-1}$ ) were calculated by depth increment using measured bulk densities and summing over all increments. Dry combustion at $600^{\circ} \mathrm{C}$ was also used to measure total organic $\mathrm{C}$ in biosolids grab-samples. 
TABLE 1: Minimum, maximum, and mean concentrations for selected biosolids constituents and total loading of dry matter (DM) and by constituent based on treatment rate, application area, and years of application (adapted from [17]).

\begin{tabular}{|c|c|c|c|c|c|c|c|c|}
\hline \multicolumn{5}{|c|}{ Biosolids application rate $\left(\mathrm{Mg} \mathrm{ha}^{-1} \mathrm{yr}^{-1}\right)$} & 20 & 40 & 60 & 20 \\
\hline \multicolumn{5}{|c|}{ Application duration (yr) } & 8 & 8 & 8 & $20^{\dagger}$ \\
\hline \multicolumn{5}{|c|}{ Treatment area (ha) } & 20 & 36 & 49 & 14 \\
\hline Biosolids constituent $^{\ddagger}$ & Unit & Min & Max & Mean & \multicolumn{4}{|c|}{ Total loading, $\mathrm{Mg}(\mathrm{DM}) \mathrm{ha}^{-1}$} \\
\hline Total solids & $\%$ & 15.2 & 19.3 & 17.6 & 160 & 320 & 480 & 400 \\
\hline Total organic $\mathrm{C}$ & $\mathrm{kg} \mathrm{Mg}^{-1}$ & 296.1 & 321.6 & 307.9 & 49.3 & 98.5 & 147.8 & 123.1 \\
\hline Total Kjeldahl N & $\mathrm{kg} \mathrm{Mg}^{-1}$ & 27.8 & 67.9 & 52.1 & 8.3 & 16.7 & 25.0 & 20.8 \\
\hline Total P & $\mathrm{kg} \mathrm{Mg}^{-1}$ & 13.4 & 29.1 & 16.1 & 2.6 & 5.2 & 7.7 & 6.4 \\
\hline $\mathrm{K}$ & $\mathrm{kg} \mathrm{Mg}^{-1}$ & 0.2 & 3.4 & 1.5 & 0.2 & 0.5 & 0.7 & 0.6 \\
\hline $\mathrm{pH}$ & - & 8.2 & 8.7 & 8.5 & - & - & - & - \\
\hline Electrical conductivity & $\mathrm{mS} \mathrm{cm}^{-1}$ & 2.7 & 3.9 & 3.5 & - & - & - & - \\
\hline
\end{tabular}

${ }^{\dagger}$ Annual applications in this treatment reduced to biennial applications of $5 \mathrm{Mg} \mathrm{ha}^{-1} \mathrm{yr}^{-1}$ in 2007.

${ }^{\ddagger}$ Environmental Protection Agency (EPA) or Standard Methods (SM) protocols used to quantify each constituent, in order listed: SW846 9060A; EPA 351.2; SM 4500-P BE; EPA 6020; SM 4500-H; EPA 9045D; SM 2540G.

TABLE 2: Means (se) for selected soil properties in biosolids-amended soils $(0-30 \mathrm{~cm})$.

\begin{tabular}{|c|c|c|c|c|}
\hline Application rate $\left(\mathrm{Mg} \mathrm{ha}^{-1} \mathrm{yr}^{-1}\right)$ & 20 & 40 & 60 & 20 \\
\hline Application duration (yr) & 8 & 8 & 8 & $20^{\mathrm{a}}$ \\
\hline Sand $^{\mathrm{b}}(\%)$ & $21.3(2.3)$ & $22.2(2.9)$ & $24.4(1.6)$ & $25.5(2.1)$ \\
\hline Silt (\%) & $55.0(1.0)$ & $56.1(1.3)$ & $53.5(1.7)$ & $52.7(0.6)$ \\
\hline Clay (\%) & $23.7(2.0)$ & $21.7(2.1)$ & $22.1(1.3)$ & $21.8(2.0)$ \\
\hline $\mathrm{pH}$ & $7.50(0.03)$ & $7.60(0.04)$ & $7.62(0.03)$ & $7.49(0.03)$ \\
\hline Electrical conductivity $\left(\mathrm{mS} \mathrm{cm}^{-1}\right)$ & $0.69(0.03)$ & $0.70(0.04)$ & $0.74(0.12)$ & $0.54(0.05)$ \\
\hline Extractable $\mathrm{NO}_{3}^{-}\left(\mathrm{mg} \mathrm{N} \mathrm{kg}^{-1}\right)$ & $25.4(6.8)$ & $31.8(3.6)$ & $39.5(8.5)$ & $14.3(1.2)$ \\
\hline Water-soluble $\mathrm{PO}_{4}^{3-}\left(\mathrm{mg} \mathrm{P} \mathrm{kg}^{-1}\right)$ & $55.0(21.1)$ & $22.2(2.3)$ & $28.6(2.2)$ & $90.4(7.5)$ \\
\hline Particulate organic matter $\left(\mathrm{mg} \mathrm{g}^{-1}\right)$ & $10.9(1.0)$ & $8.6(0.4)$ & $9.2(1.1)$ & $12.9(1.0)$ \\
\hline
\end{tabular}

${ }^{a}$ Annual applications in this treatment reduced to biennial applications of $5 \mathrm{Mg} \mathrm{ha}^{-1} \mathrm{yr}^{-1}$ in $2007 .{ }^{\mathrm{b}}$ Particle size distributions (sand, silt, and clay) were

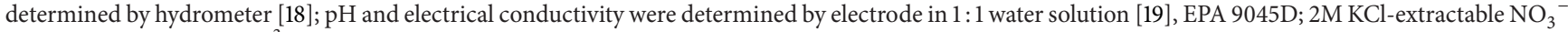
and water-extractable $\mathrm{PO}_{4}{ }^{3-}$ were measured in 1:10 soil extracts using continuous flow colorimetry (EPA 353.2, EPA 365.5); and particulate organic matter $(0.5-2.0 \mathrm{~mm})$ was measured by weight loss on ignition [20].

Water-stable aggregates were determined using the single sieve method [23] using soil aggregates in the $1-2 \mathrm{~mm}$ size range for $0-5,5-10,10-15,15-25$, and $25-35 \mathrm{~cm}$ depth increments. Aggregates in this size class were isolated by retaining $2 \mathrm{~mm}$ sieved air-dried soil passed through a $1 \mathrm{~mm}$ mesh sieve. Air-dried aggregates were prewetted with a fine mist for $1 \mathrm{hr}$ using a commercial humidifier prior to direct immersion at a rate of 35 times per min for $3 \mathrm{~min}$. The fraction of initial soil mass remaining was considered water-stable, and values were converted to a mass-per-area basis using soil bulk densities for each soil depth and summed for total water stable aggregates in the entire $0-35 \mathrm{~cm}$ soil depth.

Soil water characteristic curves were developed for $0-5$, $5-10,10-15$, and $15-25 \mathrm{~cm}$ soil increments to evaluate management impacts on near-surface soil hydraulic properties. Air-dried soils from 3 to 5 replicate cores were wetted to a range of different volumetric water contents $(\sim 0.04$ to $0.20 \mathrm{~m}^{3} \mathrm{~m}^{-3}$ ), sealed for a $24-36 \mathrm{hr}$ equilibration period, and then measured for soil matric potential using a chilled-mirror dewpoint psychrometer (WP4-T, Decagon Devices, Pullman, WA) calibrated with a certified $0.1 \mathrm{~mol} \mathrm{~kg}^{-1} \mathrm{KCl}$ salt solution. Nonlinear equations were fitted to measured data using a power function. Fitted equations were used to estimate soil volumetric water content $\left(\mathrm{m}^{3} \mathrm{~m}^{-3}\right)$ at permanent wilting point (PWP) and field capacity (FC) for soil matric potential values of $-1.5 \mathrm{MPa}$ and $-0.033 \mathrm{MPa}$, respectively. Available water capacity (AWC; $\mathrm{m}^{3} \mathrm{~m}^{-3}$ ) was defined as the difference in volumetric water content between FC and PWP.

2.3. Statistical Analyses. The absence of field replication in this municipally designed land-application operation precluded the use of analyses of variance to evaluate results. Instead, effects of biosolids application rate $(0,20,40$, and $60 \mathrm{Mg}$ dry biosolids $\mathrm{ha}^{-1} \mathrm{yr}^{-1}$ for 8 years) on measured soil physical and chemical properties were evaluated using regression analyses. Linear regressions were fit to data unless significant lack-of-fit indicated that a nonlinear regression was necessary. The effect of biosolids application duration was assessed for differences between $8 \mathrm{yr}$ and $20 \mathrm{yr}$ of application at $20 \mathrm{Mg}$ dry biosolids $\mathrm{ha}^{-1} \mathrm{yr}^{-1}$ using two-tailed $t$-tests for groups with unequal variances. Means were considered different at the 0.05 significance level. To explore potential relationships between $D_{b}$ and SOC with WSA and AWC, 
TABLE 3: Soil bulk density $\left(D_{b}, \mathrm{Mg} \mathrm{m}^{-3}\right)$ and moisture properties estimated from soil water characteristic curves fitted to power functions $\left(y=a x^{b}\right)$ for individual replicate cores $(n)$ per treatment. Ranges in coefficients of variation $\left(R^{2}\right)$ for curve fits and means (se) shown for soil water content $\left(\mathrm{m}^{3} \mathrm{~m}^{-3}\right)$ at permanent wilting point $\left(\theta_{\mathrm{PWP}}\right)$, field capacity $\left(\theta_{\mathrm{FC}}\right)$, and available water capacity $(\mathrm{AWC})$ in $0-5,5-10,10-15$, and $15-25 \mathrm{~cm}$ soils.

\begin{tabular}{|c|c|c|c|c|c|c|c|c|}
\hline $\begin{array}{l}\text { Soil depth } \\
\mathrm{cm}\end{array}$ & $\begin{array}{c}\text { Rate } \\
\mathrm{Mgha}^{-1} \mathrm{yr}^{-1}\end{array}$ & $\begin{array}{c}\text { Duration } \\
\text { Years }\end{array}$ & $\begin{array}{c}D_{b} \\
\mathrm{Mg} \mathrm{m}^{-3}\end{array}$ & $n$ & $R^{2}$ & $\begin{array}{c}\theta_{\mathrm{PWP}} \\
\mathrm{m}^{3} \mathrm{~m}^{-3}\end{array}$ & $\begin{array}{c}\theta_{\mathrm{FC}} \\
\mathrm{m}^{3} \mathrm{~m}^{-3}\end{array}$ & $\begin{array}{c}\text { AWC } \\
\mathrm{m}^{3} \mathrm{~m}^{-3}\end{array}$ \\
\hline \multirow{5}{*}{$0-5$} & 0 & 0 & $1.06(0.06)$ & 5 & $0.846-0.987$ & $0.099(0.006)$ & $0.223(0.021)$ & $0.124(0.017)$ \\
\hline & 20 & 8 & $1.21(0.04)$ & 4 & $0.908-0.990$ & $0.121(0.009)$ & $0.327(0.025)$ & $0.207(0.019)$ \\
\hline & 40 & 8 & $0.94(0.08)$ & 4 & $0.918-0.989$ & $0.126(0.018)$ & $0.391(0.049)$ & $0.265(0.031)$ \\
\hline & 60 & 8 & $1.01(0.05)$ & 2 & $0.811-0.934$ & $0.281(0.054)$ & $0.907(0.032)$ & $0.625(0.086)$ \\
\hline & 20 & 20 & $0.93(0.01)$ & 4 & $0.816-0.991$ & $0.129(0.008)$ & $0.353(0.023)$ & $0.224(0.017)$ \\
\hline \multirow{5}{*}{$5-10$} & 0 & 0 & $1.23(0.03)$ & 5 & $0.864-0.988$ & $0.118(0.002)$ & $0.235(0.012)$ & $0.117(0.011)$ \\
\hline & 20 & 8 & $1.25(0.01)$ & 4 & $0.972-0.994$ & $0.100(0.004)$ & $0.270(0.019)$ & $0.169(0.015)$ \\
\hline & 40 & 8 & $1.32(0.02)$ & 4 & $0.954-0.976$ & $0.110(0.010)$ & $0.318(0.021)$ & $0.208(0.015)$ \\
\hline & 60 & 8 & $1.36(0.05)$ & 2 & $0.903-0.973$ & $0.155(0.015)$ & $0.535(0.031)$ & $0.380(0.016)$ \\
\hline & 20 & 20 & $1.20(0.01)$ & 4 & $0.885-0.995$ & $0.125(0.003)$ & $0.333(0.009)$ & $0.208(0.006)$ \\
\hline \multirow{5}{*}{$10-15$} & 0 & 0 & $1.30(0.05)$ & 4 & $0.904-0.968$ & $0.109(0.007)$ & $0.223(0.025)$ & $0.114(0.018)$ \\
\hline & 20 & 8 & $1.36(0.07)$ & 3 & $0.970-0.994$ & $0.103(0.006)$ & $0.292(0.009)$ & $0.189(0.009)$ \\
\hline & 40 & 8 & $1.32(0.04)$ & 4 & $0.963-0.996$ & $0.102(0.010)$ & $0.289(0.018)$ & $0.187(0.012)$ \\
\hline & 60 & 8 & $1.32(0.05)$ & 2 & $0.960-0.971$ & $0.113(0.005)$ & $0.431(0.011)$ & $0.318(0.016)$ \\
\hline & 20 & 20 & $1.29(0.04)$ & 4 & $0.971-0.992$ & $0.116(0.004)$ & $0.281(0.019)$ & $0.165(0.016)$ \\
\hline \multirow{5}{*}{$15-25$} & 0 & 0 & $1.34(0.03)$ & 5 & $0.876-0.979$ & $0.107(0.002)$ & $0.229(0.009)$ & $0.121(0.007)$ \\
\hline & 20 & 8 & $1.31(0.05)$ & 4 & $0.961-0.993$ & $0.103(0.005)$ & $0.295(0.025)$ & $0.192(0.021)$ \\
\hline & 40 & 8 & $1.35(0.04)$ & 4 & $0.944-0.986$ & $0.100(0.009)$ & $0.314(0.022)$ & $0.214(0.022)$ \\
\hline & 60 & 8 & $1.33(0.05)$ & 2 & $0.940-0.986$ & $0.107(0.014)$ & $0.506(0.019)$ & $0.399(0.017)$ \\
\hline & 20 & 20 & $1.29(0.05)$ & 4 & $0.968-0.994$ & $0.113(0.002)$ & $0.278(0.010)$ & $0.166(0.010)$ \\
\hline
\end{tabular}

percent values for SOC (soil concentration) and WSA (\% mass remaining) were used instead of stocks per unit area to avoid autocorrelations between these metrics and $D_{b}$. Statistical tests were conducted using SAS 9.3 (SAS Inc., Cary, NC).

\section{Results and Discussion}

3.1. Soil Organic Carbon and Total Nitrogen Stocks. To assess the extent to which surface-applied biosolids affected SOC and total $\mathrm{N}$ with soil depth, SOC and total $\mathrm{N}$ stocks were evaluated to a $45 \mathrm{~cm}$ soil depth in this study, deeper than most published studies on surface-applied biosolids. Here, surface application rates were positively correlated with SOC and total $\mathrm{N}$ in the top $15 \mathrm{~cm}$ soil layer, somewhat deeper than other studies reporting that SOC and $\mathrm{N}$ gains are limited to the top $<10 \mathrm{~cm}$ of soils [24-27]. The current results underscore the fact that the effects of application rate and duration on SOC and total N stocks can be highly variable and depend on biosolids-specific composition as well as site-specific factors (e.g., soils, management) $[5,7,28]$.

When examined for the entire profile depth sampled $(0-45 \mathrm{~cm})$, soil stocks of SOC increased nonlinearly with application rate after $8 \mathrm{yr}$ of continuous annual applications (Figure 1(a)). A previous study using laboratory incubations to evaluate $\mathrm{C}$ and $\mathrm{N}$ mineralization responses in these soils reported similar increases in SOC (32 to 92\%) in 0-10 cm soils treated with biosolids relative to untreated control soils [22].
Other field studies on repeated surface-applied biosolids also have found increases in SOC $[4,12,24-27,29]$ and found that increases are positively correlated with application rate $[4,25]$. Site-specific increases in SOC have been reported for application rates as low as 2 to $7 \mathrm{Mg} \mathrm{ha}^{-1} \mathrm{yr}^{-1}[24,30]$. Field studies following a single application of surface-applied biosolids also report increases in SOC [8, 30-33].

Long-term applications of $20 \mathrm{Mg}$ biosolids $\mathrm{ha}^{-1} \mathrm{yr}^{-1}$ over $20 \mathrm{yr}$ resulted in a $36 \%$ increase in SOC stocks compared to the $8 \mathrm{yr}$ treatment at the same rate (Figure $1(\mathrm{a})$ ). In contrast, Gaskin et al. [26] reported that SOC levels were not different between bermudagrass fields receiving repeated surface applications for $<6 \mathrm{yr}$ or for $>6 \mathrm{yr}$, though SOC levels in both treatments were higher than unamended fields. Longterm gains in SOC have been reported in other studies which found that increased SOC or SOM levels can persist up to 27 yr after biosolids applications have ceased [24, 25, 29, 3436].

Soil total $\mathrm{N}$ stocks $(0-45 \mathrm{~cm})$ followed similar trends to SOC, increasing nonlinearly with biosolids application rate (Figure $1(\mathrm{~b})$ ). In soils treated with $20 \mathrm{yr}$ of biosolids applications at the lowest rate, total soil $\mathrm{N}$ stocks were $32 \%$ greater in long-term treated fields compared to midterm fields. In midterm fields, increasing application rates resulted in greater relative increases in total $\mathrm{N}$ stocks compared to SOC stocks. Higher enrichment in total N compared to SOC following biosolids application is well documented [5, 22, 25, $32,33,37]$ and could increase the risk of potential $\mathrm{N}$ losses 


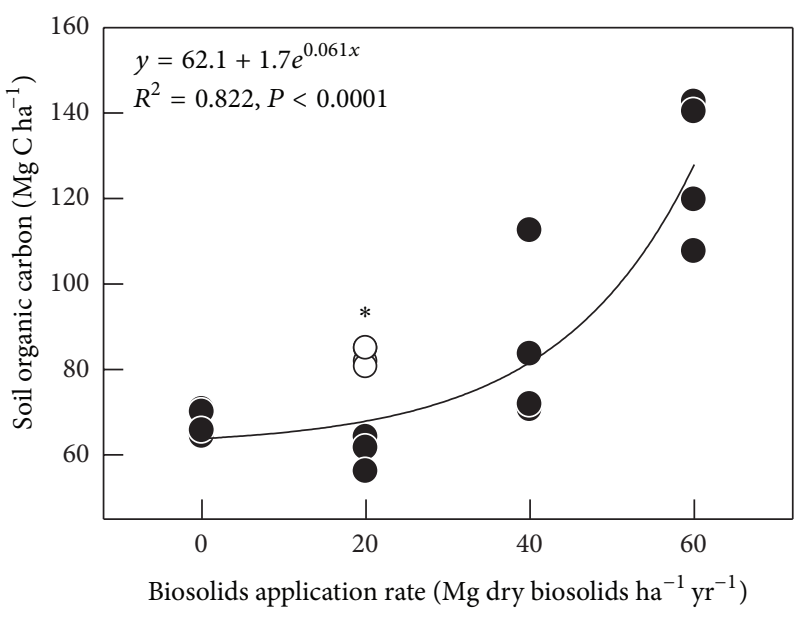

(a)

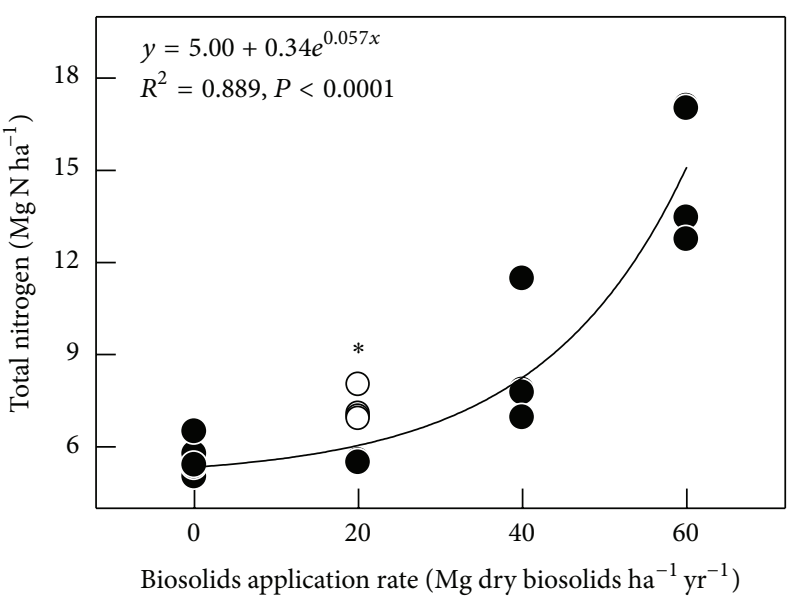

(b)

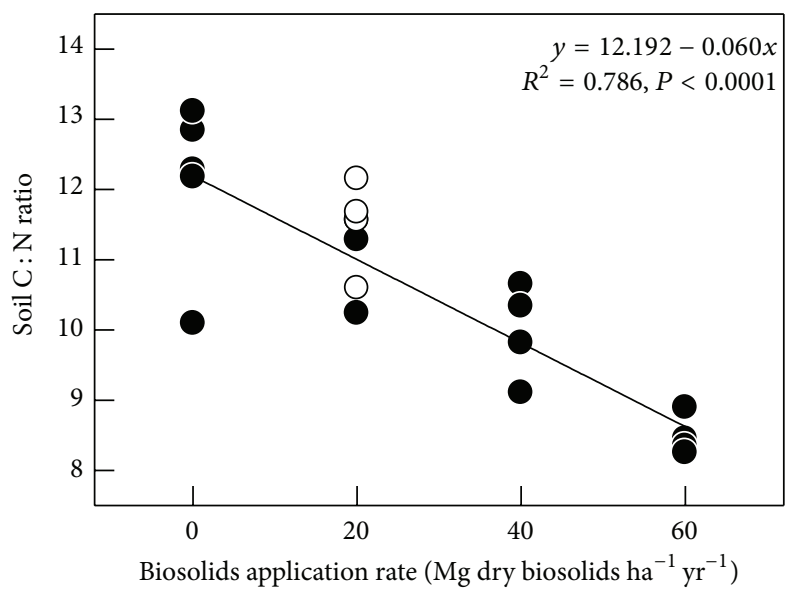

(c)

FIGURE 1: Effect of biosolids application for $8 \mathrm{yr}$ (midterm; solid symbols) at four treatment rates on (a) soil organic carbon stocks (Mg C ha ${ }^{-1}$, 0-45 cm); (b) total nitrogen stocks $\left(\mathrm{Mg} \mathrm{Nha}^{-1}, 0-45 \mathrm{~cm}\right)$; and (c) carbon-to-nitrogen ratio $(0-45 \mathrm{~cm})$. Open symbols show long-term applications of $20 \mathrm{Mg}$ biosolids $\mathrm{ha}^{-1} \mathrm{yr}^{-1}$ for $20 \mathrm{yr}$ (not included in regression shown). The asterisk indicates significant difference between midterm and long-term treatments $(P<0.05)$.

by increasing direct $\mathrm{N}$ inputs and by stimulating organic $\mathrm{N}$ mineralization $[5,38]$. Using laboratory incubations from soils at this site, Jin et al. [22] found that biosolids applications resulted in more volatile fluctuations in potential $\mathrm{N}$ mineralization and immobilization in surface soils $(0-$ $10 \mathrm{~cm}$ ) amended at the two higher application rates but not in midterm or long-term soils applied at the lowest rate relative to control soils. A more recent study, however, reported elevated soil nitrate- $\mathrm{N}$ concentrations throughout the whole soil profile $(0-110 \mathrm{~cm})$ in all biosolids-treated fields compared to unamended control [17]. Further, nitrate- $\mathrm{N}$ concentrations were $>25 \mathrm{mg} \mathrm{N} \mathrm{kg}^{-1}$ in subsoils deeper than $50 \mathrm{~cm}$ and were potentially below the predominant rooting zone, indicating an increased risk of $\mathrm{N}$ leaching losses [17]. In contrast to these findings, a recent literature review reported that increases in soil organic $\mathrm{N}$ with repeated organic matter inputs can enhance long-term availability of $\mathrm{N}$ to crops, often without resulting in greater nitrate leaching to groundwater [5].

Mean values for soil $\mathrm{C}: \mathrm{N}$ decreased linearly with increasing biosolids application rates, from $12.1 \pm 0.5$ in unamended control soils to $11.1 \pm 0.3,10.0 \pm 0.3$, and $8.5 \pm 0.1$ for 20, 40, and $60 \mathrm{Mg} \mathrm{ha}^{-1} \mathrm{yr}^{-1}$, respectively (Figure 1(c)). Soils under long-term application had a $\mathrm{C}: \mathrm{N}$ of $11.5 \pm 0.3$, similar to control soils. Measured soil $\mathrm{C}: \mathrm{N}$ values were within the range of reported values following biosolids applications [6, $24,33,37,39$ ] and followed expected decreases in $\mathrm{C}: \mathrm{N}$ values associated with increasing rates or repeated applications of biosolids [6].

3.2. Soil Bulk Density. Soil bulk densities $\left(D_{b}\right)$ for individual soil depth increments were generally similar across application rates, except in $5-10 \mathrm{~cm}$ soils where $D_{b}$ tended to increase with biosolids application rate (Table 3, Figures 3(a) and 3(b)). For the $20 \mathrm{Mg}$ biosolids $\mathrm{ha}^{-1} \mathrm{yr}^{-1}$ rate, longterm applications improved $D_{b}$ (e.g., decreased $D_{b}$ ) in the two surface soil increments $(0-5 \mathrm{~cm}, 5-10 \mathrm{~cm})$ compared to the midterm treatment. When aggregated to $0-45 \mathrm{~cm}$ depth, however, $D_{b}$ were similar between control and biosolidsamended soils. Earlier studies for soils from this site report contrasting effects of biosolids additions on $D_{b}$. Jin et al. 
[22] reported no effects of biosolids applications on $D_{b}$ in $0-10 \mathrm{~cm}$ soils. Haney et al. [17] found that $D_{b}$ in $0-30 \mathrm{~cm}$ soils increased with application rate, presumably as a result of higher wheel traffic required to land-apply at greater biosolids rates, but not with application duration at the lowest rate [17]. Results from the current study and previous reports are consistent with the variability in soil responses found in other studies on surface-applied biosolids which have reported no effects or increased $D_{b}[12,32,33,40]$ or decreased $D_{b}$ due to biosolids application $[24,27]$.

In contrast, decreases in $D_{b}$ following the incorporation of biosolids into soils are reported commonly [4, 6, 9-11, 13, 16, 41-43]. The physical mixing of soils alone decreases $D_{b}$. Depending on application rate, the incorporation of biosolids can further contribute to lowering $D_{b}$ by diluting soil mineral fractions with biosolids organic matter (OM) and subsequently increasing soil microporosity $[9,10,13]$. Surface broadcasting biosolids at this no-till perennial forage production site limited the impact of physically disturbing and homogenizing biosolids with surface soils. Changes to $D_{b}$, therefore, could be attributed to wheel traffic and other management practices associated with forage production. The absence of $D_{b}$ changes with application rate observed here could be a result of the breakdown of biosolids into fine powder over time (and, in this case, with increased wheel traffic), which would limit changes to $D_{b}$ compared to more discrete biosolids aggregates [40]. Improvements in $D_{b}$ in the long-term field relative to the midterm field also suggest that biosolids applications at the lowest rate can result in improvements in this specific soil physical quality metric.

3.3. Soil Water-Stable Aggregates. Water-stable aggregates (WSA) as a percent of whole soil decreased with increasing application rate in midterm applied fields at all measured soil depths relative to unamended controls. When converted to a mass-per-area basis, soil WSA decreased linearly with application rate at each soil depth and for the full 0 $35 \mathrm{~cm}$ profile (Figure 2). Soil WSA was also lower in longterm applied fields compared to the midterm fields at the $20 \mathrm{Mg} \mathrm{ha}^{-1} \mathrm{yr}^{-1}$ application rate, but in the $0-5 \mathrm{~cm}$ soil increment only (Figure 2(a)). Long-term decreases in soil WSA in near-surface soils also resulted in overall decreases in WSA observed for the full $0-35 \mathrm{~cm}$ profile (Figure 2(f)).

Organic amendments such as biosolids tend to increase soil physical fertility primarily by improving aggregate stability [5]. Measurement of water-stable aggregates specifically addresses the potential for soil loss by water erosion and the potential to maintain soil structure which affects the transmission and retention of water. While organic amendments can increase soil aggregate stability by 1 - to 10 -fold, stability responses vary both spatially and temporally $[4,9,11,13$, $15,44]$. Stability will also be affected by application rate and frequency, though aggregate stability is not always positively correlated with application rate [11]. Greater plant growth and soil biological activity associated with organic matter additions are the key to increasing aggregate formation and stability. Organic inputs from aboveground (e.g., plant litter) and belowground (e.g., root litter and exudates, microbial turnover and exudates) are essential for aggregate cohesion or water repellency $[6,11,25,31-33,39,41]$. Despite reported increases in microbial activity [22] and greater forage yields with increasing biosolids additions (J. Slagle, personal communication), WSA at all soil depths and for whole soils $(0-35 \mathrm{~cm})$ decreased with application rate and duration, in contrast to the majority of studies finding increases in aggregate stability after biosolids additions.

Both no change and variable changes in aggregate stability have been reported in surface-applied and incorporated biosolids studies [13, 16, 40,43]. Only few studies have reported decreases in aggregate stability following additions of biosolids, animal manure, or other organic amendments [44-46]. Degradation of aggregates and decreased stability may be due to biosolids composition, specifically the increase in compounds directly or indirectly involved in the dispersion of fine soil particles. Dispersive agents in biosolids include humic substances $[10,45]$, anionic and nonionic surfactants [37], and high amounts of $\mathrm{Na}^{+}, \mathrm{K}^{+}$, and/or organic $\mathrm{P}[14,44]$. While the composition of organic compounds in biosolids used here is beyond the scope of this study, a recent study reported that extractable $\mathrm{K}$ in these soils is not affected by biosolids rate or duration but that mineralization of organic P likely has contributed to high ortho-phosphate levels in the top $30 \mathrm{~cm}$ of soil [17]. In addition, soils at this site are calcareous, and the presence of calcium carbonates is expected to contribute to flocculation and aggregation [14]. Increases in biosolids-derived organic $\mathrm{P}$, however, could bind to clay minerals and increase clay dispersion [44] or reduce the activities of $\mathrm{Al}^{3+}$ or $\mathrm{Ca}^{2+}$ which are known aggregate bonding agents [14].

3.4. Soil Water Characteristics and Moisture Retention. Soil volumetric water contents tended to be higher at both permanent wilting point (PWP; $-1.5 \mathrm{MPa}$ ) and field capacity $(\mathrm{FC} ;-0.033 \mathrm{MPa})$ in biosolids-amended soils relative to unamended controls (Table 3 ). Values generally were within the range reported for fine-textured soils $[4,9,40]$. Despite relatively high $R^{2}$ values for soil moisture characteristic curves fitted to soils treated with the $60 \mathrm{Mgha}^{-1} \mathrm{yr}^{-1}$ application rate, estimates of volumetric water content at $\mathrm{FC}$ were high at all soil depths, possibly due to the limited number of replicate cores used and/or high SOC levels. Available water capacity (AWC) also increased with biosolids application rate and, to a lesser extent, with increased duration of application. Changes in soil water characteristics in biosolids-amended soils were detectable to $35 \mathrm{~cm}$ depth, with the largest changes occurring in $0-10 \mathrm{~cm}$ surface soils.

Other studies have also found that surface-applied biosolids increase soil water retention at FC and PWP [27, $30,37,40]$. Increases in soil surface area after OM addition may contribute to greater water retention at PWP [10] while increased microporosity enhanced water retention at FC [9]. Increased soil water retention at PWP and/or FC has been found to be positively correlated with application rate in some cases $[10,30,47]$ but not others $[40,48]$. Changes in soil water retention, however, are soil-specific and are typically greater for coarser-textured soils compared to finer-textured soils such as those in the current study $[9,10,30,37,40]$. 


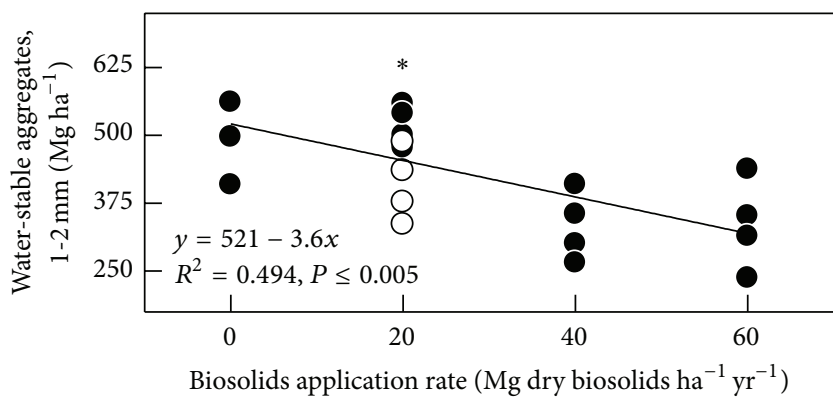

(a)

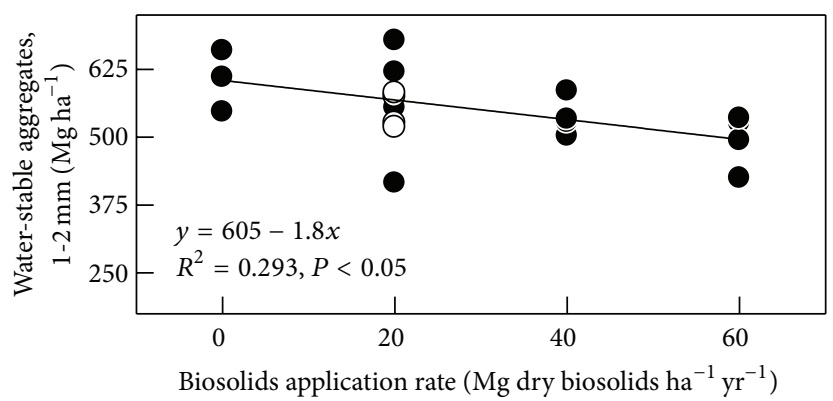

(c)

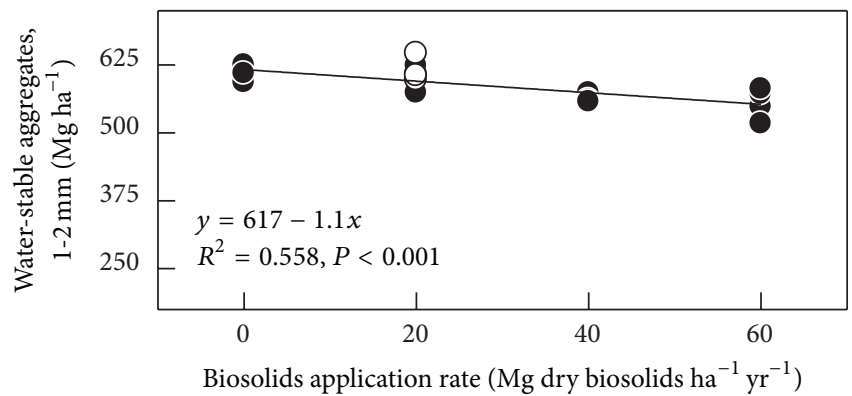

(e)

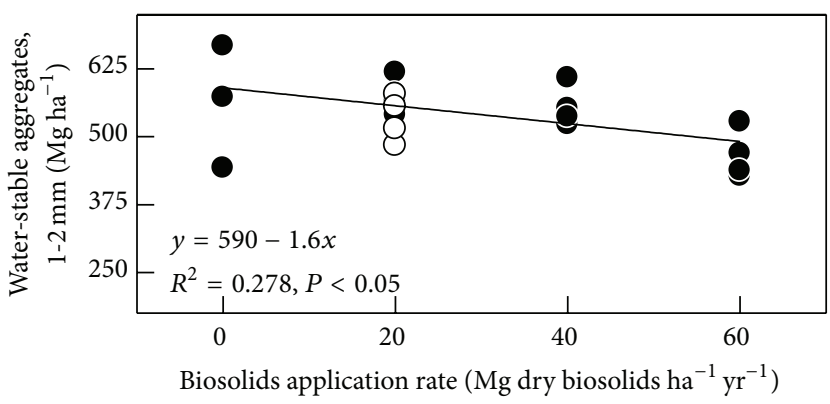

(b)

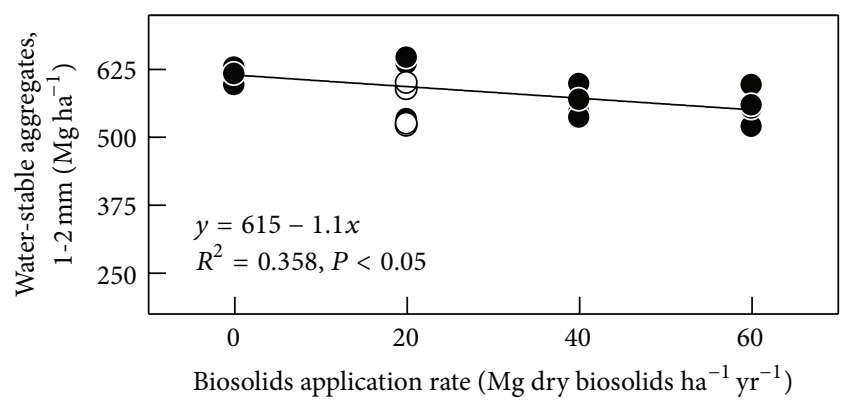

(d)

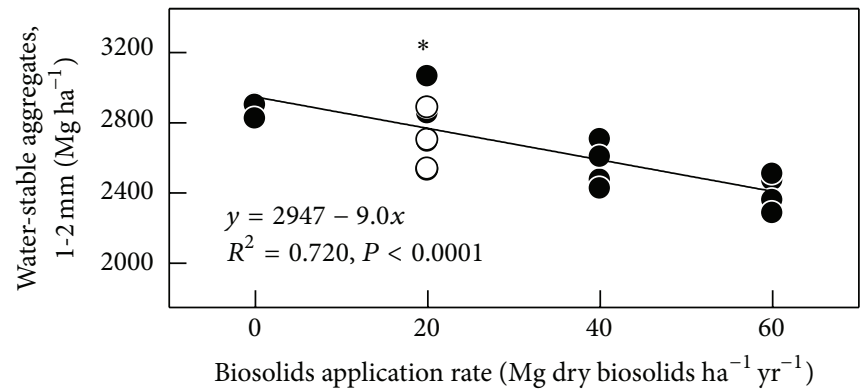

(f)

FIGURE 2: Effect of biosolids application for $8 \mathrm{yr}$ (midterm; solid symbols) at four treatment rates on soil water-stable aggregates (1-2 mm; $\mathrm{Mg} \mathrm{ha}^{-1}$ ) in (a) 0-5 cm; (b) 5-10 cm; (c) 10-15 cm; (d) $15-25 \mathrm{~cm}$; (e) $25-35 \mathrm{~cm}$; and (f) whole soil, 0-35 cm. Open symbols show long-term applications of $20 \mathrm{Mg}$ biosolids $\mathrm{ha}^{-1} \mathrm{yr}^{-1}$ for $20 \mathrm{yr}$ (not included in regression shown). The asterisk indicates significant difference between midterm and long-term treatments $(P<0.05)$.

In the review by Kladivko and Nelson [40], small but nonsignificant increases in AWC occurred with surfaceapplied biosolids additions, though a more recent review of biosolids recycling studies in Washington, USA, showed variable effects of biosolids on AWC for a range of different textured soils [4]. Improvements in water retention with no increases in AWC have also been measured in studies of incorporated biosolids [8-10]. These studies report AWC on a gravimetric basis, however, and changes in AWC are generally assumed to be nonsignificant on a volumetric basis [9]. This contrasts with findings in this study that, even if AWC values from the highest application rate are omitted, biosolids additions enhanced volumetric AWC which also increased with biosolids application rate and duration.

3.5. Relationships between SOC and Soil Physical Properties. In general, biosolids applications tend to decrease $D_{b}$, increase total porosity, and increase soil moisture retention primarily through addition of biosolids-derived organic matter $[5,6,10,11,13,42,47]$. In addition to enhancing organic C inputs to the soil, added organic matter improves $D_{b}$ (e.g., decreases $D_{b}$ ) by increasing the proportional distribution of micropores involved in water storage $(0.5-50 \mu \mathrm{m})$ and transmission $(50-500 \mu \mathrm{m})[10,13]$. Increases in microporosity subsequently can lead to increased soil water retention and improvement of other soil hydraulic properties. In this system, however, improvements in soil physical properties and SOC due to biosolids application could be offset by increased wheel traffic required to apply higher rates.

In this study, expected decreases in soil $D_{b}$ and increases in WSA (\% mass remaining) associated with greater SOC concentrations $(\% \mathrm{C})$ were not observed (Figures 3(a)-3(c)), but increased SOC was linked to greater soil AWC (Figure $3(\mathrm{~d})$ ). Soil $D_{b}$ was generally unchanged by biosolids application rate in the midterm, but long-term improvements in $D_{b}$ were not associated with greater WSA or AWC in either surface soil increment $(0-5 \mathrm{~cm}$, 


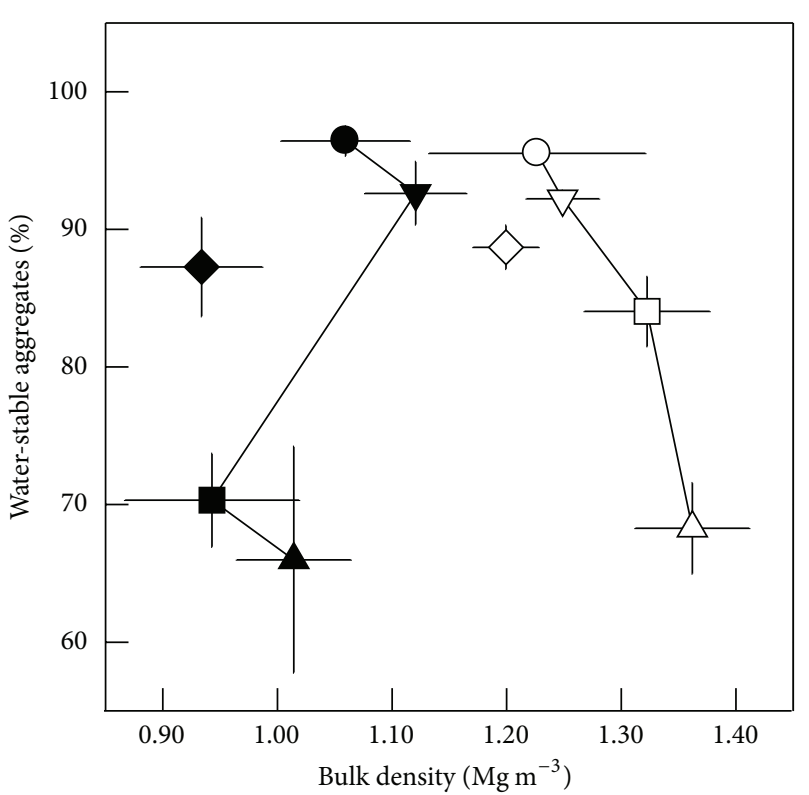

(a)

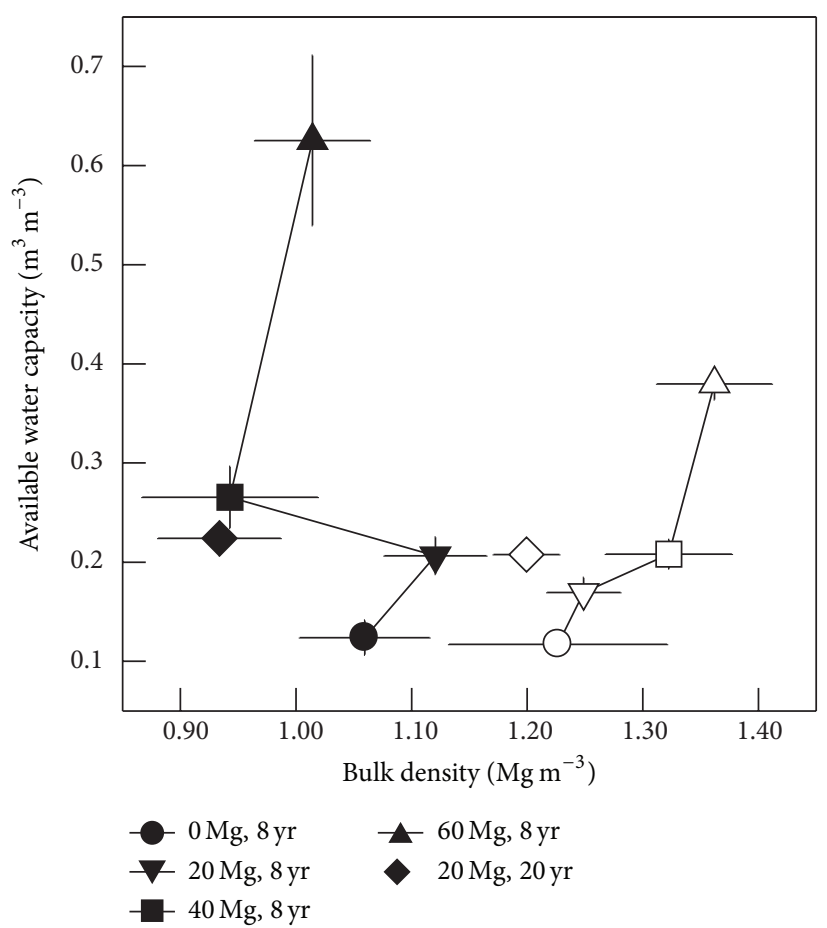

(c)

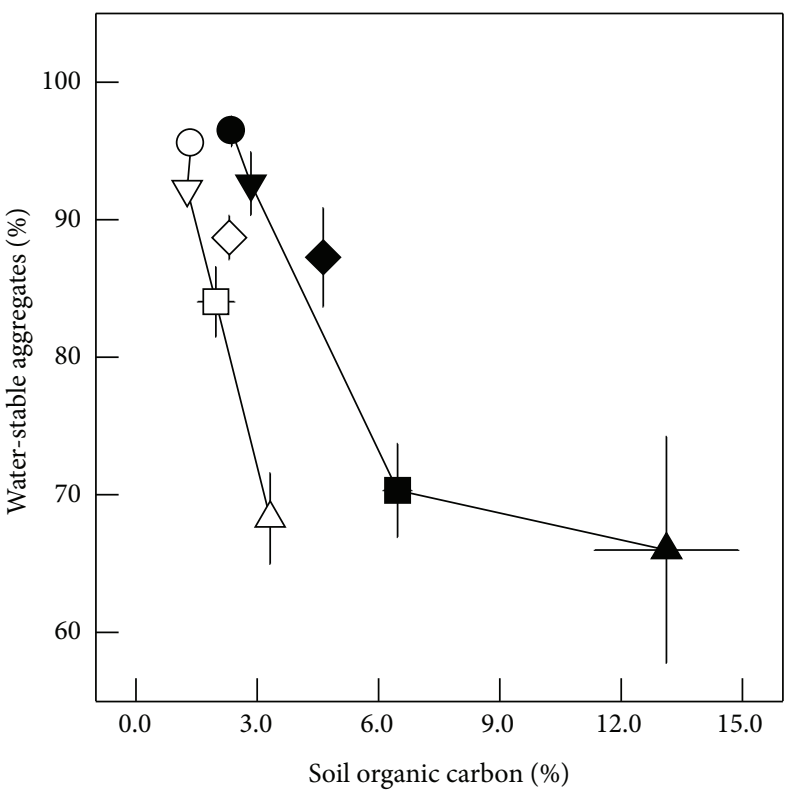

(b)

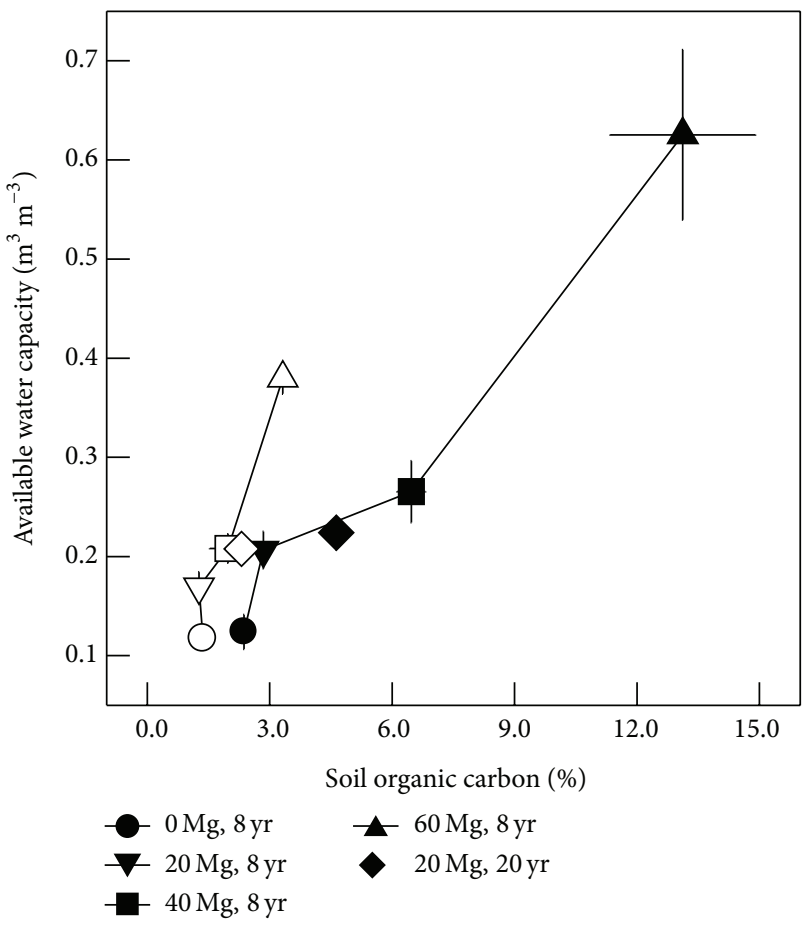

(d)

FIGURE 3: Effect of biosolids application rate and duration on relationships between (a) soil water-stable aggregates (\% mass remaining) and soil bulk density $\left(\mathrm{Mg} \mathrm{m}^{-3}\right)$, (b) soil available water capacity $\left(\mathrm{m}^{3} \mathrm{~m}^{-3}\right)$ and soil bulk density, (c) soil water-stable aggregates and soil organic carbon $(\% \mathrm{C})$, and $(\mathrm{d})$ soil available water capacity and soil organic carbon. Closed symbols show $0-5 \mathrm{~cm}$ soils; open symbols show $5-10 \mathrm{~cm}$ soils. Means (se) are shown, and symbols occasionally obscure se bars.

5-10 cm). Further, neither midterm nor long-term increases in SOC ameliorated biosolids management impacts on WSA, which generally declined in all biosolids-amended soils.

\section{Conclusions}

Land applying biosolids can serve multiple functions in addition to the beneficial reuse of wastes, including replacement 
of commercial fertilizers for crop production, improvement of soil condition, and storage of organic carbon in managed soils. In this study, we demonstrated that surface applications of biosolids can enhance SOC levels and improve soil hydraulic properties. Measured increases in SOC with application rate, however, were not associated with improvements in soil bulk density or soil aggregate stability reported in many other studies. Even under long-term application at the lowest rate where SOC increased and $D_{b}$ improved, degradation of soil WSA still occurred. These results demonstrate the potential for carbon storage in soils treated with surface-applied biosolids, but the contrasting effects of biosolids applications on soil physical properties underscore the importance of site-specific management decisions to minimize costs and maximize benefits associated with recycling biosolids in agricultural settings.

\section{Disclaimer}

Mentioning of trade names or commercial products in this paper does not imply recommendation or endorsement by the U.S. Department of Agriculture.

\section{Conflict of Interests}

The authors declare that there is no conflict of interests regarding the publication of this paper.

\section{Acknowledgments}

This project was supported by the Agriculture and Food Research Initiative Competitive Grant no. 2008-35101-04440 to J. G. Arnold from the USDA National Institute of Food and Agriculture. The authors thank K. Anderson, D. Greene, J. Slagle, and D. White from the study site for their cooperation and E. Janacek for field and laboratory assistance. USDA is an equal opportunity provider and employer.

\section{References}

[1] G. M. King, J. P. Brooks, S. S. Brown, C. Gerba, G. A. O’Connor, and I. L. Pepper, Land Application of Organic Residuals: Public Health Threat or Environmental Benefit, American Society for Microbiology, Washington, DC, USA, 2011.

[2] NEBRA, A National Biosolids Regulation, Quality, End Use, and Disposal Survey, North East Biosolids and Residuals Association, Tamworth, NH, USA, 2007.

[3] USEPA, Standards for the Use or Disposal of Sewage Sludge: Final Rules (Federal Register, 40 CFR Part 503), U.S. Environmental Protection Agency, Washington, DC, USA, 1993.

[4] S. Brown, K. Kurtz, A. Bary, and C. Cogger, "Quantifying benefits associated with land application of organic residuals in washington state," Environmental Science and Technology, vol. 45, no. 17, pp. 7451-7458, 2011.

[5] M. Diacono and F. Montemurro, "Long-term effects of organic amendments on soil fertility. A review," Agronomy for Sustainable Development, vol. 30, no. 2, pp. 401-422, 2010.

[6] R. J. Haynes, G. Murtaza, and R. Naidu, "Inorganic and organic constituents and contaminants of biosolids : implications for land application," Advances in Agronomy, vol. 104, pp. 165-267, 2009.

[7] S. I. Torri, R. S. Corrêa, and G. Renella, "Soil carbon sequestration resulting from biosolids application," Applied and Environmental Soil Science, vol. 2014, Article ID 821768, 9 pages, 2014.

[8] B. J. Lindsay and T. J. Logan, "Field response of soil physical properties to sewage sludge," Journal of Environmental Quality, vol. 27, no. 3, pp. 534-542, 1998.

[9] R. Khaleel, K. R. Reddy, and M. R. Overcash, "Changes in soil physical properties due to organic waste applications: a review," Journal of Environmental Quality, vol. 10, no. 2, pp. 133-141, 1981.

[10] I. Metzger and B. Yaron, "Influence of sludge organic matter on soil physical properties," in Advances in Soil Science, vol. 7, pp. 141-163, 1987.

[11] S. Abiven, S. Menasseri, and C. Chenu, "The effects of organic inputs over time on soil aggregate stability-a literature analysis," Soil Biology and Biochemistry, vol. 41, no. 1, pp. 1-12, 2009.

[12] C. E. Stewart, R. F. Follett, J. Wallace, and E. G. Pruessner, "Impact of biosolids and tillage on soil organic matter fractions: implications of carbon saturation for conservation management in the Virginia coastal plain," Soil Science Society of America Journal, vol. 76, no. 4, pp. 1257-1267, 2012.

[13] M. Pagliai, G. Guidi, and M. LaMarca, "Effects of sewage sludges and composts on soil porosity and aggregation," Journal of Environmental Quality, vol. 10, no. 4, pp. 556-561, 1981.

[14] R. J. Haynes and R. Naidu, "Influence of lime, fertilizer and manure applications on soil organic matter content and soil physical conditions: a review," Nutrient Cycling in Agroecosystems, vol. 51, no. 2, pp. 123-137, 1998.

[15] M. Annabi, Y. Le Bissonnais, M. Le Villio-Poitrenaud, and S. Houot, "Improvement of soil aggregate stability by repeated applications of organic amendments to a cultivated silty loam soil," Agriculture, Ecosystems and Environment, vol. 144, no. 1, pp. 382-389, 2011.

[16] R. Albiach, R. Canet, F. Pomares, and F. Ingelmo, "Organic matter components, aggregate stability and biological activity in a horticultural soil fertilized with different rates of two sewage sludges during ten years," Bioresource Technology, vol. 77, no. 2, pp. 109-114, 2001.

[17] R. L. Haney, V. L. V. L. Jin, M.-V. V. Johnson, M. J. White, and J. G. Arnold, "On-site assessment of extractable soil nutrients after long-term biosolids applications to perennial forage," Communications in Soil Science and Plant Analysis. In press.

[18] G. W. Gee and D. Or, "Particle-size analysis," in Methods of Soil Analysis: Part 4, J. H. Dane and G. C. Topp, Eds., pp. 255-293, SSSA, Madison, Wis, USA, 2002.

[19] G. W. Thomas, "Soil pH and soil acidity," in Methods of Soil Analysis, D. L. Sparks, Ed., Part 3, pp. 475-490, SSSA, Madison, Wisc, USA, 1996.

[20] C. Cambardella, A. M. Gajda, J. W. Doran, B. J. Wienhold, and T. A. Kettler, "Estimation of particulate and total organic matter by weight loss-on-ignition," in Assessment Methods for Soil Carbon, J. M. Kimble, R. F. Follett, and B. A. Stewart, Eds., pp. 349-359, CRC Lewis, Boca Raton, Fla, USA, 2001.

[21] Soil Survey Staff, "Web Soil Survey," USDA-Natural Resources Conservation Service, 2007, http://websoilsurvey.sc .egov.usda.gov/.

[22] V. L. Jin, M.-V. V. Johnson, R. L. Haney, and J. G. Arnold, "Potential carbon and nitrogen mineralization in soils from a perennial forage production system amended with class B biosolids," Agriculture, Ecosystems and Environment, vol. 141, no. 3-4, pp. 461-465, 2011. 
[23] W. D. Kemper and R. C. Rosenau, "Aggregate stability and size distribution," in Methods of Soil Analysis. Part 1, A. Klute, Ed., pp. 425-442, ASA and SSSA, Madison, Wis, USA, 1986.

[24] C. G. Cogger, A. I. Bary, E. A. Myhre, and A.-M. Fortuna, "Biosolids applications to tall fescue have long-term infl uence on soil nitrogen, carbon, and phosphorus," Journal of Environmental Quality, vol. 42, no. 2, pp. 516-522, 2013.

[25] J. A. Ippolito, K. A. Barbarick, M. W. Paschke, and R. B. Brobst, "Infrequent composted biosolids applications affect semi-arid grassland soils and vegetation," Journal of Environmental Management, vol. 91, no. 5, pp. 1123-1130, 2010.

[26] J. W. Gaskin, R. B. Brobst, W. P. Miller, and E. W. Tollner, "Longterm biosolids application effects on metal concentrations in soil and bermudagrass forage," Journal of Environmental Quality, vol. 32, no. 1, pp. 146-152, 2003.

[27] I. Mariscal-Sancho, B. C. Ball, and F. Peregrina, "Soil quality dynamics following long-term application of poultry manure and sewage sludge on Grassland," Communications in Soil Science and Plant Analysis, vol. 42, no. 6, pp. 656-668, 2011.

[28] J. M. Soriano-Disla, J. Navarro-Pedreño, and I. Gómez, "Contribution of a sewage sludge application to the short-term carbon sequestration across a wide range of agricultural soils," Environmental Earth Sciences, vol. 61, no. 8, pp. 1613-1619, 2010.

[29] M. B. McBride and L. J. Evans, "Trace metal extractability in soils and uptake by bromegrass 20 years after sewage sludge application," Canadian Journal of Soil Science, vol. 82, no. 3, pp. 323-333, 2002.

[30] C. A. Moffet, R. E. Zartman, D. B. Wester, and R. E. Sosebee, "Surface biosolids application: effects on infiltration, erosion, and soil organic carbon in Chihuahuan Desert grasslands and shrublands," Journal of Environmental Quality, vol. 34, no. 1, pp. 299-311, 2005.

[31] G. Ojeda, J. M. Alcañiz, and Y. Le Bissonnais, "Differences in aggregate stability due to various sewage sludge treatments on a Mediterranean calcareous soil," Agriculture, Ecosystems \& Environment, vol. 125, no. 1-4, pp. 48-56, 2008.

[32] R. Ryals, M. Kaiser, M. S. Torn, A. A. Berhe, and W. L. Silver, "Impacts of organic matter amendments on carbon and nitrogen dynamics in grassland soils," Soil Biology and Biochemistry, vol. 68, pp. 52-61, 2014.

[33] B. M. Wallace, M. Krzic, T. A. Forge, K. Broersma, and R. F. Newman, "Biosolids increase soil aggregation and protection of soil carbon five years after application on a crested wheatgrass pasture," Journal of Environmental Quality, vol. 38, no. 1, pp. 291298, 2009.

[34] G. Tian, T. C. Granato, A. E. Cox, R. I. Pietz, C. R. Carlson Jr., and Z. Abedin, "Soil carbon sequestration resulting from longterm application of biosolids for land reclamation," Journal of Environmental Quality, vol. 38, no. 1, pp. 61-74, 2009.

[35] P. Mantovi, G. Baldoni, and G. Toderi, "Reuse of liquid, dewatered, and composted sewage sludge on agricultural land: effects of long-term application on soil and crop," Water Research, vol. 39, no. 2-3, pp. 289-296, 2005.

[36] J. Li and G. K. Evanylo, "The effects of long-term application of organic amendments on soil organic carbon accumulation," Soil Science Society of America Journal, vol. 77, no. 3, pp. 964973, 2013.

[37] G. Ojeda, E. Perfect, J. M. Alcañiz, and O. Ortiz, "Fractal analysis of soil water hysteresis as influenced by sewage sludge application," Geoderma, vol. 134, no. 3-4, pp. 386-401, 2006.
[38] M. Zaman, M. Matsushima, S. X. Chang et al., "Nitrogen mineralization, $\mathrm{N}_{2} \mathrm{O}$ production and soil microbiological properties as affected by long-term applications of sewage sludge composts," Biology and Fertility of Soils, vol. 40, no. 2, pp. 101109, 2004.

[39] C. Nicolás, J. N. Kennedy, T. Hernández, C. García, and J. Six, "Soil aggregation in a semiarid soil amended with composted and non-composted sewage sludge-a field experiment," Geoderma, vol. 219-220, pp. 24-31, 2014.

[40] E. J. Kladivko and D. W. Nelson, "Changes in soil properties from application of anaerobic sludge," Journal of the Water Pollution Control Federation, vol. 51, no. 2, pp. 325-332, 1979.

[41] P. Bergkvist, N. Jarvis, D. Berggren, and K. Carlgren, "Longterm effects of sewage sludge applications on soil properties, cadmium availability and distribution in arable soil," Agriculture, Ecosystems and Environment, vol. 97, no. 1-3, pp. 167-179, 2003.

[42] C. E. Clapp, S. A. Stark, D. E. Clay, and W. E. Larson, "Sewage sludge organic matter and soil properties," in The Role of Organic Matter in Modern Agriculture, Y. Chen and Y. Avnimelech, Eds., vol. 25, pp. 209-253, Martinus Nijhoff Publishers, Dordrecht, The Netherlands, 1986.

[43] T. J. Logan and B. J. Harrison, "Physical characteristics of alkaline stabilized sewage sludge (N-Viro Soil) and their effects on soil physical properties," Journal of Environmental Quality, vol. 24, no. 1, pp. 153-164, 1995.

[44] A. I. Mamedov, B. Bar-Yosef, I. Levkovich et al., "Amending soil with sludge, manure, humic acid, orthophosphate and phytic acid: effects on aggregate stability," Soil Research, vol. 52, no. 4, pp. 317-326, 2014.

[45] M. Tejada and J. L. Gonzalez, "Application of different organic wastes on soil properties and wheat yield," Agronomy Journal, vol. 99, no. 6, pp. 1597-1606, 2007.

[46] J. K. Whalen and C. Chang, "Macroaggregate characteristics in cultivated soils after 25 annual manure applications," Soil Science Society of America Journal, vol. 66, no. 5, pp. 1637-1647, 2002.

[47] C. D. Tsadilas, I. K. Mitsios, and E. Golia, "Influence of biosolids application on some soil physical properties," Communications in Soil Science and Plant Analysis, vol. 36, no. 4-6, pp. 709-716, 2005.

[48] B. J. Zebarth, G. H. Neilsen, E. Hogue, and D. Neilsen, "Influence of organic waste amendments on selected soil physical and chemical properties," Canadian Journal of Soil Science, vol. 79, no. 3, pp. 501-504, 1999. 

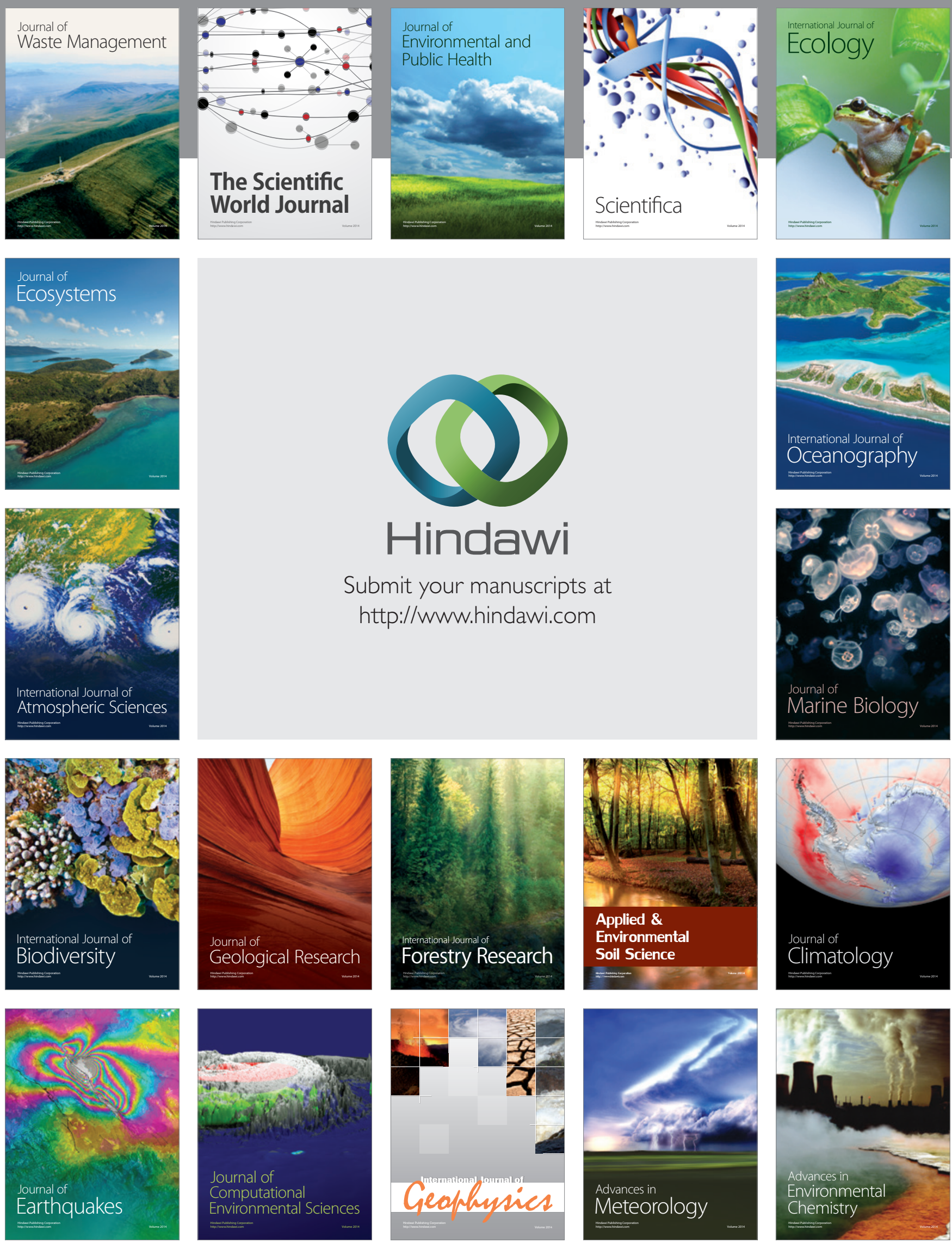